\title{
Determinants of Internet Financial Reporting in Indonesian Local Governments
}

\author{
Warsidi $^{*}$, Wahyu Rizkiyaningsih ${ }^{2}$, Oman Rusmana $^{3}$, Sukirman ${ }^{4}$ \\ ${ }^{1}$ School of Business and Economics, University of Jenderal Soedirman \\ ${ }^{2}$ School of Business and Economics, University of Jenderal Soedirman \\ ${ }^{3}$ School of Business and Economics, University of Jenderal Soedirman \\ *Email corresponding author: contact@warsidi.com
}

\begin{abstract}
Local Governments are expected to provide relevant information related to their finance and performance to the public through the media that is easily accessible in order to meet the principles of accountability and transparency. The financial information through internet is called IFR (Internet Financial Reporting) which is a combination between the internet multimedia capability and capacity to communicate the financial information interactively. The objective of this study is to empirically examine determinants of internet financial reporting by local government in Indonesia.

This study uses five variables there are Political Competition, Size, Dependency, Wealth and Type of Local Government. The sample in this study selected with purposive sampling. Total sample in this study are 130 local governments which contain 97 regency $(74,6 \%)$ and 33 municipal $(25,4 \%)$. Analysis method used in this study is multiple liner regression. The result shows that political competition, size and wealth of local government have a positive influence to the internet financial reporting in Indonesia. Two other variables, dependency and type of local government do not significantly affect to the internet financial reporting in Indonesian local goverments.
\end{abstract}

Keywords: internet financial reporting, local government, Indonesia.

\begin{abstract}
Abstrak
Pemerintah daerah diharapkan mampu menyediakan informasi yang relevan yang terkait dengan kinerja keuangan kepada publik melalui media yang mudah diakses sesuai dengan prinsip akuntabilitas dan transparansi. Penyajian informasi keuangan melalui internet atau yang dikenal dengan istilah IFR (Internet Financial Reporting) merupakan kombinasi kemampuan internet dan multimedia untuk menyampaikan informasi keuangan secara interaktif. Penelitan ini dimaksudkan untuk menguji secara empiris determinan-determinan implementasi IFR oleh pemerintah daerah di Indonesia.

Lima variabel digunakan: Persaingan Politik, Ukuran, Ketergantungan, Kekayaan dan Tipe Pemerintah Daerah. Sampel dipilih secara purposif sejumlah 130 pemerintah daerah yang terdiri dari 97 kabupaten $(74,6 \%)$ dan 33 kota $(25,4 \%)$. Metode analisis yang digunakan adalah regresi linear multivariabel. Hasilnya menunjukkan bahwa persaingan politik, ukuran dan kekayaan pemerintah daerah berpengaruh positif terhadap IFR di Indonesia. Dua variabel lainnya, ketergantungan dan tipe pemerintahan tidak berhubungan signifikan dengan IFR di Indonesia.
\end{abstract}

Kata-kata kunci: IFR, pemerintah daerah, Indonesia.

\section{INTRODUCTION}

Reforms in the area of financial management started with Law Number 17 Year 2003 regarding State Finance, which requires the form and content of the report accountability of the State Budget (APBN) or Regional Government Budget (APBD). The financial statements must be audited by the Supreme Audit Agency (BPK) to assess the validity and reliability of the information related to the management and responsibility of the state finance (Martani, et.al., 2014). In the scope of local government, accountability for financial management by local governments should not be given to Parliament as the representative of the people only, but also to the general public (Diani, 2016).

Attention to the issue of transparency in Indonesia has increased since the issuance of Law No. 14 of 2008 regarding Public Information. Every public information should be obtained each applicant's public information 
quickly and timely, low cost, and simple ways, for example by using internet media. One form of transparency that can be achieved by governments is to publish financial reports through the Internet. Data from the website of Internet World Status shows that Indonesia was ranked as the third country most internet users in Asia. We can see the use of internet in Asia on the diagram below.

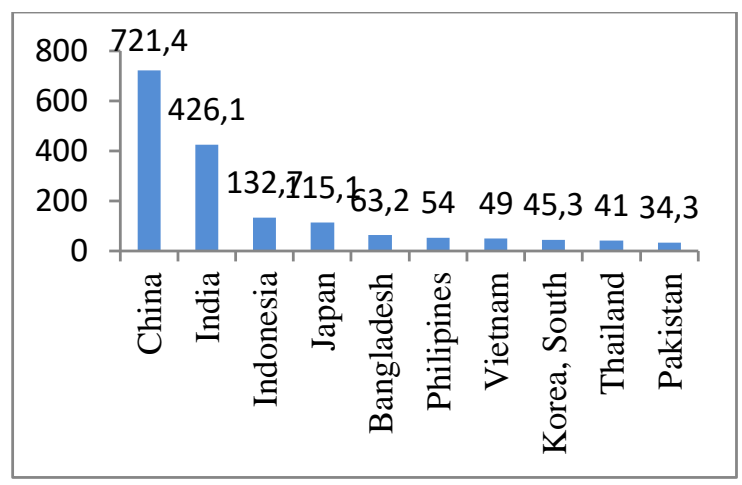

Source: $w$ ww.internetworldstats.com

Figure 1 Top Ten Internet Countries in Asia 2016

Nowadays, almost all local governments in Indonesia already have a website but with different quality and roles. Financial reporting through the website by the local government is one way to carry out the principle of accountability. In Indonesia, the development of website used by local governments began with the issuance of Presidential Instruction Number 6 year 2001 concerning Development and Utilization of Telematics (Information and Communication Technology) in Indonesia, which is clarified by Presidential Instruction Number 3 year 2003 concerning the National Policy and Strategy of E-Government Development.

Some previous research tries to examine the factors that affecting financial reporting on the internet by local government but did not provide consistent results. First research conducted by Laswad, et.al., (2005) with five variable, there are political competition, size, leverage, wealth, and type of local government.

This study referred to the previous study conducted by Laswad, et. al., (2005). However, based on the study there are two independent variables that not used anymore, namely leverage and press visibility. Leverage replace with the variable dependency of local government because the public sector is still rarely to get a loan from the private party, but local governments more often receive funding from the central government. For the press visibility variable is not use anymore because the level of difficulty to obtain sufficient data is high.

Research that conducted by Laswad, et.al., (2005) prove that political competition was not found to be useful predictors of internet financial reporting. While, the results study of Rahman, et.al., (2013) shows that political competition proved to affect the internet financial reporting.

The dependency of local government revenues to the central government will cause more pressure for the local government to meet regulations of the central government. Martani, et.al., (2014) prove that there is a positive correlation between the level of dependency on the central government with the level of disclosure on the internet. In contrast with research conducted by Junaedi (2015) shows that dependence area does not affect the disclosure on local government internet-based financial reporting.

Medina (2012) prove that the size of government significant positive effect on the availability of financial information on the official website of the local government. It is not consistent with Laswad (2005) research that shows the size of local government were not found to be useful predictors of internet financial reporting.

The higher level of regional wealth will further encourage local governments to disclose its finances through the internet. According to Hudoyo \& Mahmud (2014) research found that regional wealth does not affect to the internet financial reporting by local governments in Indonesia. Those results do not correspond with the research results from Laswad (2005) that shows internet financial reporting can be predicted based on the government wealth.

Martani, et.al., (2014) found there is no correlation between the type of government and the level of disclosure. Meanwhile in a research conducted by Junaedi (2015) obtained results that type of local government have a positive and significant impact on the disclosure of Internet-Based Financial Reporting by local government. 
This study addresses the following research questions: (1) whether the political competition of local government has a positive association to the internet financial reporting; (2) whether the size of local government has a positive association to the internet financial reporting; (3) whether the dependency of local government has a positive association to the internet financial reporting; (4) whether the wealth of local government has a positive association to the internet financial reporting; (5) whether the type of local government has a positive association to the internet financial reporting; and (6) whether the political competition, size, leverage, wealth, and type of local government simultaneously has a positive association to the internet financial reporting?

\section{LITERATURE REVIEW AND HYPOTHESES}

\section{Agency Theory}

An agency relationship is a contract under which one or more persons (principal) engage another person (agent) to perform some service on their behalf which involves delegating some decision making authority to the agent (Jensen \& Meckling, 1976). In financial reporting, the government who act as an agent that present useful information for users of government financial information who act as a principal in assessing accountability and make a decision as an economic, social, and political decision as well as directly or indirectly through their representative.

\section{Signaling Theory}

Signaling Theory explains that the government as a party that is given responsibility by the people have a desire to show a good signal to the society (Martani, et.al., 2014). In the framework of signals theory mentioned that the urge to provide information is due to the asymmetry of information between the local government and outside parties, especially the people. The government can increase the trust of the public by reducing the information asymmetry occurs. One way to reduce the asymmetry of information is to give a good signal to the public in the form of financial information that is positive and trustworthy (Trisnawati \& Achmad, 2014).

\section{Research Model and Hypotheses}

This study is aimed at examining the determinants of IFR in Indonesian local goverments using the following research framework.

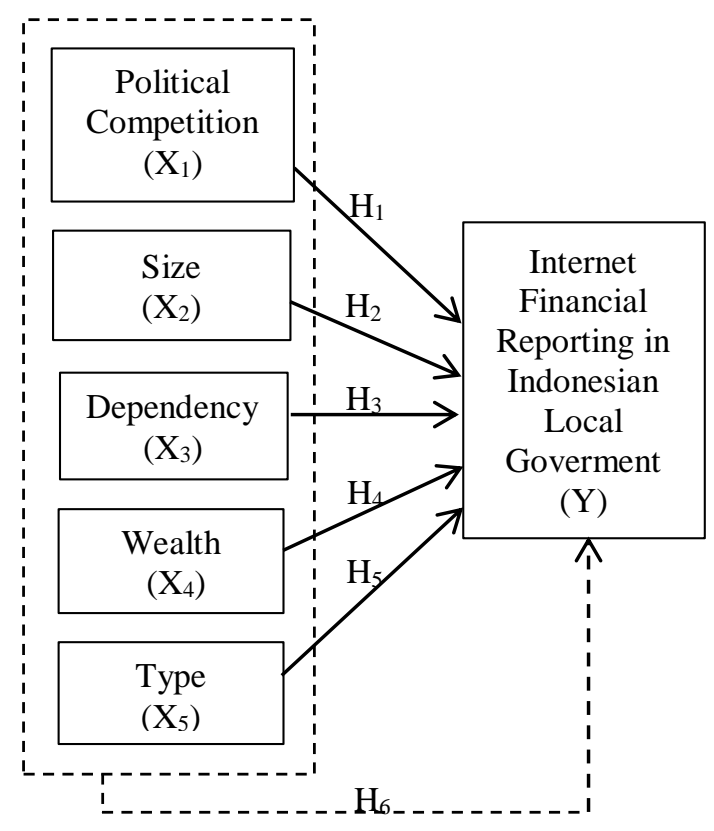

Figure 2 Research Model

Political Competition Based on Laswad et.al., (2005) research, explained that there is a positive relationship between political competition and Internet Financial Reporting (IFR). The higher level of political competition, the tendency of local governments to use the internet as a means of voluntary reporting of financial information will also be higher. Considering previous studies, the first hypothesis is as follows. 
$\mathrm{H}_{1}$ : There is a positive association between internet financial reporting and political competition of local government.

Size A big local government is also more complex in its financial management so that more financial information should be reported to reduce the asymmetry of information (Trisnawati \& Achmad, 2014). Medina (2012) shows the result that the size of local government has significant positive influence toward the availability of financial information in the official website of local government. Based on the previous research above, the formulation of the second hypothesis is as follows.

$\mathrm{H}_{2}$ : There is a positive association between internet financial reporting and size of local government.

Dependency High level of dependency tends to increase the level of disclosure. Disclosure trough the internet is one of an effective way for local government to disseminate financial reporting. Research conducted by Puspita \& Martani (2012) and Martani, et.al., (2014) proved that there is a positive correlation between the level of dependency on the central government with the level of disclosure trough internet on the local government website. Based on the analysis and previous research, the third hypothesis is as follows.

$\mathrm{H}_{3}$ : There is a positive association between internet financial reporting and dependency of local government.

Wealth The wealth of local governments reflects government performance in managing their finances. Disclosure and financial reporting do not be a problem when the performance of local government goes well. The research result from Laswad et.al., (2005) and Junaedi (2015), shows that local government wealth has a positive effect on the internet financial reporting. Based on the analysis above, the fourth hypothesis is as follows.

$\mathrm{H}_{4}$ : There is a positive association between internet financial reporting and wealth of local government.

Type of Local Government Access and use of the Internet in urban areas tend to be higher, thus encouraging the city government to make optimum use of their own website. Laswad (2005) and Junaedi (2015) shows that type of local government has a significant positive effect on internet financial reporting by local government. Based on the analysis above, the third hypothesis is as follows.

$\mathrm{H}_{5}$ : There is a positive association between internet financial reporting and type of local government.

$\mathrm{H}_{6}$ : There is a positive association between internet financial reporting index and political competition, size, dependency, wealth, and type of local government simultaneously.

\section{RESEARCH METHOD}

The type of this research is quantitative research. This type aims to describe a generalization or explain the relationship between one variable with another variable. The variables of interest are political competition, size, leverage, wealth, type of local government and the internet financial reporting.

\section{Type and Source of Data}

Data that used in this study is secondary data. The data used in this study is financial statements of local government in Indonesia year 2015 that obtained from Audit Board of the Republic of Indonesia (BPK). For the non-financial data like for political competition variable obtained from official website of General Election Commissions (www.kpu.go.id). While for the population and all of the local government website link data obtained from the official site of Ministry of Home Affairs (www.kemendagri.go.id).

\section{Population, Sample and Sample Selection Technique}

The population in this research is the local governments in Indonesia. The following criteria established by researchers in the sampling are as follows: 
a. Regency / municipal government in Indonesia

b. The local government has an official website and accessible.

c. Local government has the financial statements that have been audited by Audit Board of the Republic of Indonesia (BPK) year 2015 and can be obtained from BPK.

d. Local governments that receive unqualified opinion (WTP) from the Supreme Audit Agency (BPK).

e. Provided data and information for the measurement of research variables.

\section{Operational Variable}

The dependent variable in this research is financial reporting of local government on the internet. This research uses Internet Financial Reporting Index based on Verawaty (2014) for assessing the four components with some of the modification. IFR index modification lies in the data provided on the Indonesian government's official website. In the previous study (verawaty, 2014) financial statement component only counted 1 point based on complete or not. In this study is calculated based on financial statements items that published on website include a balance sheet, LAK, LRA, CaLK, APBD. For the format of financial statement in the previous study use HTML format only but in Indonesian local government website still rare to publish financial statement use HTML so in this study add format pdf and jpg also. The maximum sum of IFR is 14 points for each region. We can see in the table below.

Table 1 Internet Financial Reporting Index

\begin{tabular}{|r|l|l|c|}
\hline A. & Financial Highlights & $\begin{array}{l}\text { Presents summary of financial statements in } \\
\text { the form of a brief table or a brief description } \\
\text { and easily accessible }\end{array}$ & 1 point \\
\hline B. & Financial Statement & $\begin{array}{l}\text { Add 1 point on the availability of each item of } \\
\text { financial statements (balance sheet, LRA, LAK, } \\
\text { CaLK and APBD) }\end{array}$ & 5 point \\
\hline C. & Format & $\begin{array}{l}\text { Financial statements in the form of } \\
\text { html/pdf/jpg }\end{array}$ & 1 point \\
\hline D. & Data for Prior Years & $\begin{array}{l}\text { IFR also provide the previous year report for } \\
\text { comparison }\end{array}$ & 1 point \\
\hline E. & Up Date & $\begin{array}{l}\text { IFR for the current year (eg served each } \\
\text { semester so it's always updated and timely) }\end{array}$ & 1 point \\
\hline F. & Analysis Tools & Provide analysis tools (eg, Excel Pivot Table) & 1 point \\
\hline G. & Advanced Features & $\begin{array}{l}\text { Providing advanced features (such as the } \\
\text { implementation of the Intelligent Agent or } \\
\text { XBRL) }\end{array}$ & 1 point \\
\hline H. & Site Search & $\begin{array}{l}\text { The search engine in the site can be used to } \\
\text { search financial statements }\end{array}$ & 1 point \\
\hline I. & Link Page & Provides links to IFR on the website & 1 point \\
\hline J. & FAQ or Contact & $\begin{array}{l}\text { Provide question and answer facilities or } \\
\text { email/phone manager }\end{array}$ & 1 point \\
\hline
\end{tabular}

The independent variables used in this study as the determinants of Internet Financial Reporting are defined as follows:

Political Competition Based on (Rahman, et.al., 2013) political competition is the ratio of the coalition parties supporting the regional head election winner constitute.

Number of board member in coalition party

the total number of board member 
Size The size of local government illustrates the big or small of a local government. Rahman, et.al., (2013) use natural logarithm of total assets to measure the size of local government.

$$
\text { Size }=\text { Ln (total assets) }
$$

Dependency The dependency of local government is the level of dependency of local governments level two to the central government nor at the local government level one (Junaedi, 2015). The dependency of local government ratio measure by dividing a total of general allocation fund (DAU) with total income.

$$
\text { Dep }=\frac{\text { Tot of General Allocation Fund }}{\text { Total Income }}
$$

Wealth The wealth of local government describes the level of prosperity area. Accordance to Laswad et.al., (2005) measuring the wealth of local government using local revenue per capita. This study uses the same measurement with Laswad et.al., (2005) by comparing locally-generated revenue (PAD) with a population of the area.

$$
\text { Wealth }=\frac{\text { Locally }- \text { generated revenue }(P A D)}{\text { Population }}
$$

Type of Local Government Type of local government is defined as a form of local government. There are two types of local government in Indonesia, in a form of regency or municipal. This research uses same measurement with Laswad et.al., (2005). For local government type, the measurements of these variables assessed using dummy variables. Number 1 when local governments in the form municipal and 0 for regency governments in Indonesia.

\section{Data Analysis Techniques}

This study using multiple regression models to analyze the data. This model is used to determine how much the influence of the independent variable on the dependent variable. The regression models of this study can be seen in the following models:

$$
\text { IFR index }=\alpha+\beta_{1} \text { PCOM }+\beta_{2} \text { SIZE }+\beta_{3} \text { DEP }+\beta_{4} \text { WEALTH }+\beta_{5} \text { DTYPE }+\varepsilon
$$

where:

$\begin{array}{ll}\text { IFR Index } & =\text { Internet Financial Reporting Index } \\ \text { PCOM } & =\text { Political Competition of local government } \\ \text { SIZE } & =\text { Size of local government } \\ \text { DEP } & =\text { Dependency of local government } \\ \text { WEALTH } & =\text { Wealth of local government } \\ \text { DTYPE } & =\text { Dummy type of local government } \\ \alpha & =\text { Intercept (constants) } \\ \varepsilon & =\text { Error } \\ \beta_{1}, \beta_{2}, \beta_{3}, \beta_{4}, \beta_{5} & =\text { Coefficient regression }\end{array}$

Tests to be performed include descriptive statistical tests to find out the mean, median and standard deviations. After that the classical assumption test consisting of normality test, multicollinearity, and heteroscedasticity test. The accuracy of the sample regression function in assessing the actual value can be measured from the goodness of fit. Statistically, can be measured by the coefficient determination value, statistic F value and statistic $t$ value.

\section{RESULTS AND DISCUSSION}

\section{General Description of the Study}

The object of research in this study is local government covers municipal and regency in Indonesia. The sample was taken by purposive sampling method, that is using certain criteria determined by the researcher. Based on the specified sampling criteria, the number of research samples is described in the following table. 
Table 2 Summary of Sample

\begin{tabular}{|c|c|}
\hline Local Government in Indonesia & 548 \\
\hline Reduced by: & \\
\hline Provincial government & 34 \\
\hline Financial statement not available & 47 \\
\hline Non-unqualified opinion & 247 \\
\hline Website not accessible & 20 \\
\hline $\begin{array}{l}\text { Political competition data is not } \\
\text { available }\end{array}$ & 70 \\
\hline Total Sample & 130 \\
\hline
\end{tabular}

According to Table 4.1, sample (N) in this research are 130 local governments in Indonesia that contain 33 municipal and 97 regencies. From the tested sample there are $46(35,38 \%)$ that publish the financial statement on local governments official website and $84(64,62 \%)$ that not publish the financial statement on the local government official website.

\section{Descriptive Statistic Analysis}

Descriptive statistics were used to determine the value of the maximum, minimum, average, and standard deviation of each variable. From 130 sample, the results of the descriptive analysis are presented in Table 3 as follows:

Table 3 Descriptive Statistics

\begin{tabular}{lllllr}
\hline & $\mathrm{N}$ & Min & Max & Mean & $\begin{array}{c}\text { Std. } \\
\text { Deviation }\end{array}$ \\
\hline IFR & 130 & 0,00 & 11,00 & 3,1923 & 3,08559 \\
Polcom & 130 & 0,00 & 0,83 & 0,3461 & 0,17821 \\
Size & 130 & 27,32 & 32,69 & 28,7079 & 0,80493 \\
Dep & 130 & 0,09 & 0,74 & 0,5360 & 0,13832 \\
Wealth & 130 & 10,48 & 15,59 & 12,6524 & 0,75776 \\
Type & 130 & 0,00 & 1,00 & 0,2538 & 0,43689 \\
\hline
\end{tabular}

Table 4 Frequencies of Variable Type

\begin{tabular}{llll} 
& & Frequency & Percent \\
\hline \multirow{3}{*}{ Valid } & Regency & 97 & 74,6 \\
& Municipal & 33 & 25,4 \\
& Total & 130 & 100 \\
\hline
\end{tabular}

Table 3 shows the result of descriptive statistic analysis variable in the study. The dependent variable is internet financial reporting that has a maximum value 11,00 and minimum value 0,00 , with IFR Index as a variable measurement. The mean value of IFR variable is 3,1923, with those value indicate the quality of IFR in Indonesia is still low. Standard deviation value as much as 3,08559. The standard deviation value is smaller than the mean value $(3,08559<3,1923)$ it means that the results of the internet financial reporting distribution is quite good. This is because the standard deviation is a very high reflection deviation, so the spread of data shows normal results and does not cause bias.

POLCOM variable has a maximum value 0,83 (Berau Regency) and minimum value 0,00 (Labuhanbatu Selatan Regency, Pematang Siantar City, Sibolga City, Bone Bolango Regency). The mean value of POLCOM variable is 0,3461 , with those value indicate that the political competition variable in Indonesia still low. Standard deviation value as much as 0,17821 . The standard deviation value is smaller than the mean value $(0,17821<0,3461)$ it means 
that the results of the political competition distribution is quite good. This is because the standard deviation is a very high reflection deviation, so the spread of data shows normal results and does not cause bias.

Variable SIZE has the maximum value 32,69 (Tanah Datar Regency) and the minimum value is 27,32 (Bolaang Mongondow Regency). Variable SIZE has the highest mean value among all independent variables as much as 28,7079 , with those value indicate the size of local government in Indonesia is large enough. In the other word the size is good enough because it represent the assets of local government. Standard deviation value 0,80493. The standard deviation value is smaller than the mean value $(0,80493<28,7079)$ it means that the results of the size of local government distribution is quite good. This is because the standard deviation is a very high reflection deviation, so the spread of data shows normal results and does not cause bias.

The maximum value for DEP is 0,74 (Bolaang Mongondow Regency) and has the minimum value 0,09 (Badung Regency). The mean value of DEP is 0,5360 , with those value indicate that the depedency of local governmnet still high. In the other word it is not really good because many of local government in Indonesia that still depent on central government. Standard deviation value 0,13832. The standard deviation value is smaller than the mean value $(0,13832<0,5360)$ it means that the results of the dependency of local government distribution is quite good. This is because the standard deviation is a very high reflection deviation, so the spread of data shows normal results and does not cause bias.

Variable WEALTH has a maximum value 15,59 (Badung Regency) and the minimum value is 10,48 (Tanggamus Regency). The mean value of WEALTH is 12,6524 , those value indicate that wealth of local government is good enough. Standard deviation value is 0,75776 . The standard deviation value is smaller than the mean value $(0,75776$ $<12,6524$ ) it means that the results of the wealth of local government distribution is quite good. This is because the standard deviation is a very high reflection deviation, so the spread of data shows normal results and does not cause bias.

Variable TYPE that uses dummy variable for the measurement, has the maximum value 1,00 and the minimum value is 0,00 . Table 4.4 shows the frequencies of variable TYPE, it contains 97 regency $(74,6 \%)$ and 33 municipal $(25,4 \%)$.

\section{Tests of Classical Assumption}

Normality Test In this research normality test is done by one sample Kolmogorov-Smirnov test. Here are the results of normality testing using SPSS program:

Table 5 Normality Test

\begin{tabular}{|c|c|c|}
\hline & & $\begin{array}{l}\text { Unstandarized } \\
\text { Residual }\end{array}$ \\
\hline \multirow[t]{2}{*}{$\mathbf{N}$} & & 130 \\
\hline & Mean & 0,5616 \\
\hline Normal Parameters & $\begin{array}{c}\text { Std. } \\
\text { Deviation }\end{array}$ & 1,07419 \\
\hline \multirow{3}{*}{$\begin{array}{c}\text { Most } \\
\text { Differences }\end{array}$} & Absolute & 0,113 \\
\hline & Positive & 0,093 \\
\hline & Negative & $-0,113$ \\
\hline \multicolumn{2}{|l|}{ Test Statistic } & 0,113 \\
\hline \multicolumn{2}{|l|}{ Asymp. Sig. (2-tailed) } & 0,082 \\
\hline
\end{tabular}

The results of normality test data with One Sample Kolmogorov-Smirnov Test shows the value of Asymp. Sig (2tailed) as much as 0,082 higher than 0,05. So it shows that the residual data are normally distributed.

Multicollinearity Test Multicollinearity occurs when between independent variables have a significant relationship. Here are the results of multicollinearity testing use SPSS: 


\begin{tabular}{cccc} 
& \multicolumn{2}{c}{ Collinearity Statistics } \\
Model & Tolerance & VIF \\
\hline 1 & (Constant) & & \\
POLCOM & 0,785 & 1,274 \\
SIZE & 0,800 & 1,250 \\
DEP & 0,727 & 1,376 \\
& WEALTH & 0,727 & 1,376 \\
& TYPE & 0,762 & 1,312 \\
\hline
\end{tabular}

The result of calculation tolerance value shows all independent variables has tolerance value more 0.10 . The result of Variance Inflation Factor (VIF) calculation also shows that all independent variables have VIF value $<10$. So it can be concluded that there is no multicollinearity between independent variables in the regression model.

Heteroscedasticity Test Heteroscedasticity assumption test aims to determine whether in the regression model occurred inequality variance from one residual observation to another observation. If the variance of the one residuals observation same to the other observations, it is called Homoscedasticity and if different called Heteroscedasticity (Ghozali, 2013). Here are the results of heteroscedasticity testing use SPSS:

Table 7 Heteroscedasticity Test

$\begin{array}{ll}\text { Unstandarized } & \text { Standarized } \\ \text { Coefficients } & \text { Coefficients }\end{array}$

\begin{tabular}{cclllll} 
Model & & B & Std.Error & Beta & T & Sig. \\
\hline 1 & (Constant) & $-1,307$ & 5,985 & & $-0,218$ & 0,827 \\
& Polcom & 1,260 & 0,824 & 0,146 & 1,530 & 0,129 \\
& SIZE & 0,008 & 0,181 & 0,004 & 0,043 & 0,965 \\
& DEP & $-1,533$ & 1,103 & $-0,138$ & $-1,390$ & 0,167 \\
& WEALTH & 0,277 & 0,201 & 0,136 & 1,376 & 0,171 \\
& TYPE & 0,560 & 0,341 & 0,159 & 1,641 & 0,103 \\
\hline
\end{tabular}

The results of SPSS output show no independent variables that are statistically significant affect the dependent variable absolute value. This is seen from the probability value (sig) above 0.05 (sig> 0.05 ), so it can be concluded that there is no problem of heteroscedasticity.

\section{Hypothesis Testing}

Regression Model Using SPSS program, the following result are obtained:

Table 8 Regression Analysis

\begin{tabular}{cclllll}
\multicolumn{8}{c}{} & \multicolumn{5}{l}{$\begin{array}{l}\text { Unstandarized } \\
\text { Coefficients }\end{array}$} & \multicolumn{2}{l}{$\begin{array}{l}\text { Standarized } \\
\text { Coefficients } \\
\text { Model }\end{array}$} & & B & Std.Error & Beta & T & Sig. \\
\hline 1 & (Constant) & $-44,560$ & 11,062 & & $-4,028$ & 0,000 \\
& Polcom & 3,057 & 1,522 & 0,177 & 2,008 & 0,047 \\
& SIZE & 1,134 & 0,334 & 0,296 & 3,396 & 0,001 \\
& DEP & 1,201 & 2,038 & 0,054 & 0,598 & 0,557 \\
& WEALTH & 1,055 & 0,372 & 0,259 & 2,836 & 0,005 \\
& TYPE & 0,591 & 0,630 & 0,084 & 0,936 & 0,350 \\
\hline
\end{tabular}

Based on the table then the regression equation obtained is as follows: 


$$
Y=-44.560+3,057 X 1+1,134 X 2+1,201 X 3+1,055 X 4+0,591 X 5+e
$$

Determination Coefficient Test $\left(\mathbf{R}^{2}\right)$ From the determination test generated $\mathrm{R}^{2}$ value as can be seen in the table as follows:

Table 9 Result of Determination Coefficient Test

\begin{tabular}{cllll} 
Model & $\mathrm{R}$ & $\begin{array}{l}\mathrm{R} \\
\text { Square }\end{array}$ & $\begin{array}{l}\text { Adjusted } \\
\mathrm{R} \text { Square }\end{array}$ & $\begin{array}{l}\text { Std. Error of } \\
\text { the Estimate }\end{array}$ \\
\hline 1 & 0,498 & 0,248 & 0,217 & 2,72986 \\
\hline
\end{tabular}

Based on the result of determination test known that the value of adjusted $R$ square is 0,217 , which means that $21,7 \%$ variation of internet financial reporting can be explained by the variation of political competition, size, dependency, wealth, and type of local government. While the remaining $78.3 \%$, described by other variables outside the model.

Simultaneous Test (F-Test) From the simultaneous test generated $\mathrm{R}^{2}$ value as can be seen in the table as follows:

Table 10 Result of Simultaneous Test

\begin{tabular}{cclllll} 
& & \multicolumn{2}{l}{ Sum of } & \multicolumn{2}{l}{ Mean } \\
Model & & Squares & Df & Square & F & Sig. \\
\hline 1 & Regression & 304,125 & 5 & 60,825 & 8,162 & 0,000 \\
& Residual & 924,067 & 124 & 7,452 & & \\
& Total & 1228,192 & 129 & & & \\
\hline
\end{tabular}

Based on the results of the simultaneous test (F-test) in table 9 above, obtained the significance value of regression model simultaneously as much as 0,000 . The value is smaller than the significance level as much as $0,05(5 \%)$ or $0,000<0,05$. Also can be seen from the comparison between fcount and ftabel which shows the value of fcount as much as 8,162 while the ftabel is 2,99. From those results it can be seen that fcount $>\mathrm{ftabel}$ or $8,99>2,99$, so it can be concluded that simultaneously independent variables namely political competition, size, dependency, wealth, and type of local government significantly influence internet financial reporting as the dependent variable.

Partial Test (t-Test) Partial regresion analysis shows the following results:

Table 11 Result of Partial Test

\begin{tabular}{|c|c|c|c|c|c|}
\hline Model & $\mathrm{t}_{\text {stats }}$ & table & Sig. & $\alpha=5 \%$ & Result \\
\hline POLCOM & 2,008 & 1,65723 & 0,047 & 0,05 & Sig \\
\hline SIZE & 3,396 & 1,65723 & 0,001 & 0,05 & Sig \\
\hline DEP & 0,589 & 1,65723 & 0,557 & 0,05 & Not Sig \\
\hline WEALTH & 2,836 & 1,65723 & 0,005 & 0,05 & Sig \\
\hline TYPE & 0,938 & 1,65723 & 0,350 & 0,05 & Not Sig \\
\hline
\end{tabular}

a. Based on the t-test (partial) on the regression model, obtained the significance value of variable political competition $\left(\mathrm{X}_{1}\right)$ as much as $0,047<0,05$. Can be seen also from the comparison between $t_{\text {count }}$ and $t_{\text {table }}$ which shows the value of $t_{\text {count }}$ is 2,008 while the $t_{\text {tabel }}$ as much as 1,65723 .

b. Based on the t-test (partial) on the regression model, obtained the significance value of variable size $\left(\mathrm{X}_{2}\right)$ as much as $0,001<0,05$. Can be seen also from the comparison between $t_{\text {count }}$ and $t_{\text {table }}$ which shows the value of $t_{\text {count }}$ is 3.396 while the $t_{\text {tabel }}$ as much as 1,65723.

c. Based on the t-test (partial) on the regression model, obtained the significance value of variable dependency $\left(\mathrm{X}_{3}\right)$ as much as $0,557>0,05$. 
d. Based on the t-test (partial) on the regression model, obtained the significance value of variable size $\left(\mathrm{X}_{4}\right)$ as much as $0,005<0,05$. Can be seen also from the comparison between $t_{\text {count }}$ and $t_{\text {table }}$ which shows the value of $t_{\text {count }}$ is 2,836 while the $t_{\text {tabel }}$ as much as 1,65723 .

e. Based on the t-test (partial) on the regression model, obtained the significance value of a variable type of local government $\left(\mathrm{X}_{5}\right)$ as much as $0,350>0,05$. Can be seen also from the comparison between $t_{\text {count }}$ and table which shows the value of $t_{\text {count }}$ is 0,938 while the $t_{\text {tabel }}$ as much as 1,65723 .

\section{Discussioun}

Political Competition The test result with multiple linear regression shows hypothesis 1 that is political competition variable has a positive effect to internet financial reporting by local government. This can be seen from the significance value as much as $0.047<0,05$. The higher political competition in local government will be encouraging the local government to reports it's financial information on the internet.

Related to agency theory and signaling theory, political competition can be used as a predictor that motivates elected officials (agent) to perform financial reporting on the internet as a form of transparency of local financial management and its performance to the public (principal) in order to avoid information asymmetry. The local government also show positive signals to the public that they have implemented the government's performance honestly and transparently, so the regional heads have a great chance to be re-elected in the next period of elections.

Size of Local Government Size of local government which assessed from total assets proven have a positive influence on internet financial reporting by local government. This can be seen from the significance value as much as $0.001<0.05$ and positive coefficient of 3,057. The resulted from local governments with large size (total assets) make public becoming more aware of local finances transparency so the public will more stringent financial controls, this is because the high level of complexity in their regional financial management and the need for more detailed about financial information resulting in greater disclosure of local governments of their financial information to facilitate public monitoring. In accordance with agency theory and signaling theory, the increasingly critical condition of society towards the transparency of local financial management requires local government which in this case acts as an agent to give positive signal by reporting its financial information to the public (principal) to avoid information asymmetry and as a form of transparency of local financial management.

Dependency Dependency of local government which assessed from the ratio of total general of allocation fund and real income, proven has no significant influence toward internet financial reporting by local government. This can be seen from the significance value as much as 0,557 $>0,05$. The insignificant influence of local government dependency toward internet financial reporting can be due from the unpreparedness of local government in disclosing its financial statements to the public because it is still very dependent toward central government assistance, in other words the region has not been able to independently meet the needs of the region.

Wealth Wealth of local government which assessed from the ratio of locally generated revenue and population, proven has positive significant influence toward internet financial reporting by local government. This can be seen from the significance value as much as $0,005<0,05$ and positive coefficient of 1,055 . The greater wealth of local government, the higher public demand for transparency of local financial management. This is because local governments with large amounts of wealth are more likely to engage in fraud. In addition, the increasing wealth of local government shows the good performance of local government, so it motivates the local government to report its financial information. In accordance with agency theory and signaling theory, the public that acts as the principal must supervise the utilization of local wealth, and the government that acts as an agent must provide a positive signal by conveying the financial statement information to the public.

Type of Local Government Type of local government which assessed from dummy variable, proven has no significant influence toward internet financial reporting by local government. This can be seen from the significance value as much as $0,350>0,05$. The local government's decision to publish the financial statements through the internet not influenced by the type of local government. District and city governments have a tendency that does not differ in publishing financial statements on their official website. Currently, the use of the Internet has spread to all parts of Indonesia. The government has also been implementing internet into the village program since 2010. 
The result of F-Test shows hypothesis 5 , which assessed from simultaneous test, prove that simultaneously the independent variables namely political competition, size, dependency, wealth and type of local government significantly influence internet financial reporting as the dependent variable. This can be seen from the value of significance as much as $0,000<0,05$. Also can be seen from the comparison between $\mathrm{f}_{\text {count }}$ and $\mathrm{f}_{\text {tabel }}$ which shows the value of $f_{\text {count }}$ as much as 8,162 while the $f_{\text {tabel }}$ is 2,99 . From those results it can be seen that $f_{\text {count }}>f_{\text {tabel }}$ or $8,99>2,99$.

\section{CONCLUSIONS AND IMPLICATIONS}

\section{Conclusions}

Based on the results of the tests it can be seen that political competition, size of local government and wealth of local government proved that has influence toward internet financial reporting by local government. This study did not succeed in proving the positive influence between dependency and type of local government toward internet financial reporting by local government in Indonesia.

\section{Limitations}

1. This research period of research is only one year, so it can not compare the condition of internet financial reporting by local government inter-period of time.

2. Only examines the availability of financial information on official web sites of municipal and regency government.

3. The third limitation is the ability to explain the publication of local government financial statements through the internet in this study is still low. This indicates that there are some other factors that can explain publication of local government financial statements through the internet.

\section{Suggestions}

1. Future research suggested to use research with a longer period of time/time series, so can make the comparison condition of internet financial reporting by local government between a period of time.

2. Using provincial government as a sample for further research material on voluntary disclosure relating to financial information on its official website.

3. Subsequent research can add other variables that are suspected to has an influence on the publication of local government financial statements through the internet, such as audit opinion, government complexity and income per capita.

\section{Implications}

1. To motivate local governments (agent) to start building and developing local government sites as a financial publication medium which can be considered more transparent and accountable by the public (principal) and as a comparison material with other governments.

2. Provide an overview about accountability and transparency of local government financial management, so the public can assess the policies and performance of local governments as well as efforts to realize good public governance.

\section{REFERENCES}

Asosiasi Penyelenggara Jasa Internet Indonesia. 2016. Penetrasi dan Perilaku Pengguna Internet Indonesia. https://www.apjii.or.id/content/read/39/264/Survei-Internet-APJII-2016. Access on 2nd January 2016.

Diani, R. P. 2016. Analisis Determinan Pelaporan Keuangan di Internet Oleh Pemerintah Daerah di Indonesia. Thesis. Sebelas Maret University. Surakarta.

Faculty of Economics and Business Universiy of Jendral Soedirman. Thesis Guidelines International Program. Purwokerto.

Ghozali, I. 2009. Ekonometrika - Teori Konsep dan Aplikasi dengan SPSS 17. Semarang: Badan Penerbit Universitas Diponegoro.

. 2013. Analisis Aplikasi Multivariate dengan program IBM SPSS program 23. Badan Penerbit Universitas Diponegoro, Semarang. 
Halim, A., \& Abdullah, S. 2006. Hubungan dan Masalah Keagenan di Pemerintahan Daerah : Sebuah Peluang Peneliian Anggaran dan Akuntansi. Jurnal Akuntansi Pemerintahan, Vol 2, No. 1, p53-64.

Hariadi, P., Restianto, Y. E., \& Bawono, I. R. 2013. Pengelolaan Keuangan Daerah. Jakarta: Salemba Empat.

Hudoyo, Y. T., \& Mahmud, A. 2014. Faktor-Faktor yang Mempengaruhi Pengungkapan Laporan Keuangan di Internet oleh Pemerintah Daerah . Accounting Analysis Journal, 3 (4).

Indriantoro, N., \& Supomo, B. (1999). Metodologi Penelitian Bisnis Untuk Akuntansi dan Manajemen. 1st ed. Yogyakarta: BPFE-YOGYAKARTA.

Internet World Status. 2016. Internet Usage in Asia. http://www.internetworldstats.com/stats3.htm. Access on 1st January 2017.

Jensen, M. C., \& Meckling, W. H. 1976. Theory of The Firm : Managerial Behavior, Agency Costs and Ownnership Structure. Journal of Financial Economics, 3, p305-360.

Junaedi. 2015. Pengaruh Kekayaan Pemerintah Daerah, Ketergantungan Daerah, Kompleksitas, Tipe Pemerintah Daerah, Kualitas Audit dan Tinggkat Penyimpangan Anggaran Terhadap Pengungkapan Internet-Based Financial Reporting. Jurnal Sainstech Politeknik Indonusa, Vol. 2, No. 4, ISSN 2355-5009.

Laswad, F., Fisher, R., \& Oyelere, P. 2005. Determinats of Voluntary Internet Financial Reporting by Local Government Authorities. Journal of Accounting and Public Policy, 24, p101-121.

Mardiasmo. 2009. Akuntansi Sektor Publik. 4th ed. Yogyakarta: ANDI.

Martani, D., Fitriasari, D., \& Annisa. 2014. Financial and Performance Transparency on the Local Government Websites in Indonesia. Journal of Theoretical and Applied Information Technology, Vol. 60, No. 3, ISSN 1992 8645.

Medina, F. 2012. Faktor - Faktor yang Mempengaruhi Transparasi Informasi Keuangan Pada Situs Resmi Pemerintah Daerah di Indonesia. Thesis. University of Indonesia. Depok.

Puspita, R., \& Martani, D. 2012. Analisis Pengaruh Kinerja dan Karakteristik Pemda terhadap Tingkat Pengungkapan dan Kualitas Informasi Dalam Website Pemda. Journal.

Rahman, A., Sutaryo, \& Budiatmanto, A. 2013. Determinan Internet Financial Local Government Reporting di Indonesia. Simposium Nasional Akuntansi 25-28 September 2013.

Republic of Indonesia, Laws Number 17 Year 2003 Regarding State Finance. , Laws Number 1 Year 2004 Regarding State Treasury.

, Laws Number 15 Year 2004 Regarding Examination of State Financial Management and Responsibilities.

, Laws Number 32 Year 2004 Regarding Local Governemt.

, Laws Number 152006 Regarding Audit Board of the Republic Indonesia.

, Governmnet Regulation Number 58 Year 2005 Regarding Local Financial Management. Government Regulation Number 71 Year 2010 Regarding Public Accounting Standard.

Ministry of Home Affairs Regulation Number 13 Year 2006 Regarding Guidelines for Local Government Financial Management.

, Ministry of Home Affairs Regulation Number 64 of 2013 Regarding Implementation of Accrual Based Government Accounting Standards in Local Government.

, Presidential Decree Number 6 Year 2001 Concerning Development and Utilization of Telematics in Indonesia.

Presidential Decree Number 3 Year 2003 Concerning the National Policy and Strategy of EGovernment Development.

Sekaran, U. 2003. Research Methods for Business. 4th ed. New York: John Wiley \& Sons, Inc.

Sinaga, Y. F., \& Prabowo, T. J. 2011. Analisis Faktor-Faktor yang Mempengaruhi Pelaporan Keuangan di Internet Secara Sukarela oleh Pemerintah Darerah. Journal.

Styles, A. K., \& Tennyson, M. 2007. The Accessibility of Financial Reporting of U.S Municipalities on the Internet. Journal of Public Budgeting, Accounting \& Financial Management, 19 (1), p56-92.

Suliyanto. 2005. Metodologi Riset Bisnis. Yogyakarta: ANDI.

Suwardjono. 2005. Teori Akuntansi- Perekayasaan Laporan Keuangan. 4th ed. Yogyakarta: BPFE-YOGYAKARTA.

Trisnawati, D. M., \& Achmad, K. 2014. Determinan Publikasi Laporan Keuangan Pemeritah Daerah Melalui Internet. Brawijaya University.

Verawaty. 2013. Analisis Komparasi Indeks Internet Financial Reporting Pemerintah Daerah di Indonesi. Bina Darma University

2014. Determinan Aksesibilitas Internet Financial Reporting Melalui E-Government Pemerintah Daerah di Indonesia. Jurnal Universitas Bina Darma.

Yanuaraisya, A. 2016. Analisis Pengaruh Karakteristik Pemerintah Terhadap Tingkat Pengungkapan Laporan Keuangan di Website Pemerintah. Thesis. University of Lampung. 